\title{
The influence of structural modifications of dihydrophenazines on arachidonic acid mobilization and superoxide generation by human neutrophils
}

\author{
B M ZEIS, * J SAVAGE, J F O’SULLIVAN $\dagger \&$ \\ R ANDERSON \\ Division of Immunology, Department of Medical Microbiology, \\ Institute For Pathology, University of Pretoria, Republic of South \\ Africa; $\dagger$ The Health Research Board Laboratories, Chemistry \\ Department, Trinity College, Dublin, Republic of Ireland
}

\section{Accepted for publication 1 December 1989}

\begin{abstract}
Summary In this study the effects of nine dihydrophenazine derivatives, relative to clofazimine (B663), on the $\mathrm{N}$-formyl-L-methionyl-L-leucyl-L-phenylalanine (FMLP) stimulated release of superoxide anion and on the spontaneous generation of arachidonic acid by human neutrophils were investigated. Previous findings that the pro-oxidative activity of the agents depended largely on the substituion in position 2 of the phenazine molecule and on chlorination in the paraposition of the phenyl and anilino rings were confirmed. Only riminophenazines, but not aposafranone derivatives or the imidazophenazine B621, could enhance superoxide release from activated neutrophils. The lack of chlorination of the phenyl and anilino rings could be compensated for by chlorine substitution in position 7 of the phenazine core.

The priming effect of the agents on FMLP stimulated superoxide generation was completely prevented by the phospholipase $\mathrm{A}_{2}$ inhibitor 4-p-bromophenacyl bromide. Furthermore pro-oxidative activities correlated closely with a stimulatory effect of the agents on arachidonic acid release. It was therefore concluded that dihydrophenazine derivatives with pro-oxidative properties can prime neutrophils for FMLP-stimulated superoxide release by modulation of phospholipase $\mathrm{A}_{2}$ activity.
\end{abstract}

\section{Introduction}

The dihydrophenazine compound clofazimine (B663; 3-( $p$-chloroanilino)-10-( $p$-chlorophenyl)-2,10-dihydro-2-(isopropyliminophenazine)) is used for the treatment of leprosy due to its antimycobacterial, as well as its immunosuppressive properties. ${ }^{1}$ Apart from its direct antimicrobial activity it can also enhance host defence by increasing various phagocyte functions including the respiratory burst. ${ }^{2,3}$ It has also been found to augment

* Correspondence: Reichenspergerplatz 1, D-5400 Koblenz, West Germany. 
the release of reactive oxidants ${ }^{4}$ as well as of prostaglandin $E_{2}$ from polymorphonuclear and mononuclear leucocytes, ${ }^{5,6}$ both potential mediators of immunosuppression. ${ }^{7,8}$ The priming effect of clofazimine on superoxide release by human neutrophils is stimulus nonspecific and has been observed with phorbol myristate acetate (PMA), N-formyl peptides, calcium ionophore, opsonized zymosan and arachidonic acid (AA). ${ }^{9}$ Clofazimine can mobilize AA from membrane phospholipids of human neutrophils. ${ }^{10} \mathrm{AA}$ in micromolar concentrations and by a mechanism which remains to be clearly elucidated, activates NADPH-oxidase, whereas at suboptimal concentrations it can prime neutrophils to subsequent stimulation with $\mathrm{N}$-formyl peptides or the tumour promotor phorbol myristate acetate. ${ }^{11-14}$ Since phospholipase $A_{2}\left(P_{2} A_{2}\right)$ can cleave AA from membrane phospholipids $^{15}$ the priming effect of clofazimine on the release of superoxide from neutrophils could be explained by modulation of the activity of this enzyme. ${ }^{10}$

We have recently shown how structural modifications of the clofazimine molecule can influence the release of reactive oxidants ${ }^{4}$ as well as the release of $\mathrm{PGE}_{2}$ from neutrophils. ${ }^{16,17}$ The nature of the chemical group in position 2 of the phenazine ring was found to be particularly important for these activities. In the present study we have extended our previous investigations and attempted to correlate molecular structures with both pro-oxidative activity and the mobilization of AA by human neutrophils.

\section{Methods}

CHEMICALS AND REAGENTS

Unless otherwise indicated, these were obtained from Sigma Chemical Co., St Louis, Mo, USA.

\section{SELECTION AND SOLUBILIZATION OF AGENTS}

All dihydrophenazine derivatives investigated in this study were synthesized by $\mathbf{J} \mathbf{F}$ O'Sullivan. On the basis of previously published and unpublished data, nine phenazine derivatives were selected to correlate structural manipulations with effects on the release of superoxide anion and AA by human neutrophils in vitro. ${ }^{16-18}$ The chemical structures of these derivatives are shown in Figure 1. B663, B980, B670, B1865, B746, B718 and B4021 are riminophenazines while $\mathrm{B} 3722$ and $\mathrm{B} 685$ are aposafranones, in which the nitrogen in position 2 of the phenazine molecule has been replaced by oxygen. B3722 has a hydroxyl group in position 3, and $\mathrm{B} 685$ a $\rho$-chlorinated anilino ring. $\mathrm{B} 621$ is an imidazophenazine in which the phenyl and anilino rings in position 10 and 3 respectively are not chlorinated.

Ten milligrammes of each compound was solubilized in $5 \mathrm{ml}$ dimethyl sulphoxide and further diluted in distilled water to the concentrations required. All agents were compared to the appropriate solvent control.

\section{CELL PREPARATION}

Neutrophils were obtained from heparinized venous blood (5U preservative-free heparin per $\mathrm{ml}$ ), as previously described. ${ }^{3}$ The cells were suspended in indicator-free HEPES (N-2hydroxy-ethylpiperazine- $\mathrm{N}^{\prime}$-2-ethanesulphonic acid, 4.2 mM)-buffered Hanks' balanced 

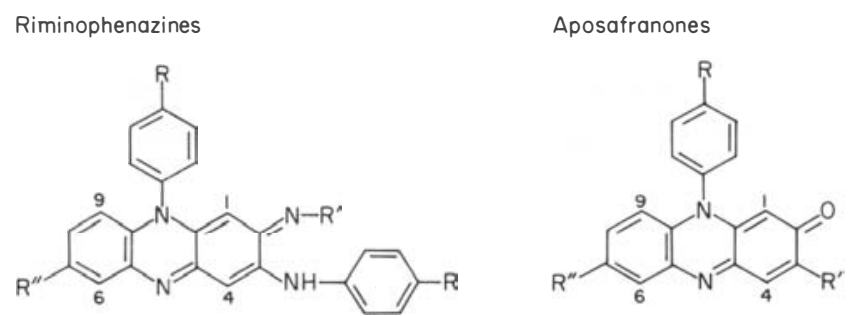

Imidazophenazines

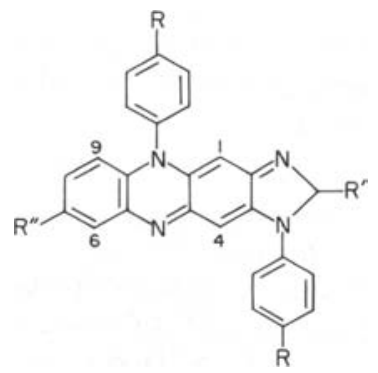

\begin{tabular}{cccc}
\hline & $\mathrm{R}$ & $\mathrm{R}^{\prime}$ & $\mathrm{R}^{\prime \prime}$ \\
\hline $\mathrm{B} 663$ & $\mathrm{Cl}$ & $\mathrm{CH}\left(\mathrm{CH}_{3}\right)_{2}$ & $\mathrm{H}$ \\
$\mathrm{B} 670$ & $\mathrm{H}$ & $\mathrm{CH}\left(\mathrm{CH}_{3}\right)_{2}$ & $\mathrm{H}$
\end{tabular}

\begin{tabular}{llll}
\hline & $\mathrm{R}$ & \multicolumn{1}{c}{$\mathrm{R}^{\prime}$} & $\mathrm{R}^{\prime \prime}$ \\
\hline $\mathrm{B} 685$ & $\mathrm{Cl}$ & $\mathrm{NH} \cdot \mathrm{C}_{6} \mathrm{H}_{4} \mathrm{Cl}$ & $\mathrm{H}$ \\
$\mathrm{B} 3722$ & $\mathrm{Cl}$ & $\mathrm{OH}$ & $\mathrm{H}$
\end{tabular}

\begin{tabular}{cccc}
\hline & $R$ & $R^{\prime}$ & $R^{\prime \prime}$ \\
\hline$B 621$ & $H$ & $\left(\mathrm{CH}_{3}\right)_{2}$ & $H$
\end{tabular}

$\mathrm{BI} 1865 \mathrm{H} \quad \mathrm{CH}\left(\mathrm{CH}_{3}\right)_{2} \quad \mathrm{Cl}$

$\mathrm{B980} \mathrm{F} \quad \mathrm{CH}\left(\mathrm{CH}_{3}\right)_{2} \quad \mathrm{H}$

$\begin{array}{llll}\mathrm{B} 746 & \mathrm{Cl} & \mathrm{C}_{2} \mathrm{H}_{5} & \mathrm{H}\end{array}$

$\begin{array}{llll}\mathrm{B} 718 & \mathrm{H} & \mathrm{C}_{2} \mathrm{H}_{5} & \mathrm{H}\end{array}$

$\begin{array}{llll}\mathrm{B} 402 \mathrm{I} & \mathrm{H} & \mathrm{C}_{2} \mathrm{H}_{5} & \mathrm{Cl}\end{array}$

Figure 1. Chemical structures of nine dihydrophenazines in comparison with clofazimine, (B663).

salt solution (HBSS; GIBCO Laboratories, Grand Island, NY, pH 7.4) and contained $>90 \%$ viable neutrophils.

\section{SUPEROXIDE-PRODUCTION BY PMNL}

The reaction mixture contained $1 \times 10^{6}$ neutrophils, $0 \cdot 1 \mu \mathrm{M}$ of the synthetic chemotactic tripeptide N-formyl-L-methionyl-L-leucyl-L-phenylalanine (FMLP), $0 \cdot 1 \mathrm{mM}$ horse heart ferricytochrome c (cyt-c; type VI) and the agent under investigation at a final concentration of $1 \mu \mathrm{g} / \mathrm{ml}$, or the corresponding solvent control in a final volume of $1 \mathrm{ml}$ HBSS with or without $100 \mathrm{U}$ of superoxide dismutase (SOD). After preincubation of the neutrophils at $37^{\circ} \mathrm{C}$ for $5 \mathrm{~min}$, cyt-c and, where applicable, SOD was added followed immediately by the test agents. FMLP was added after $5 \mathrm{~min}$ incubation at $37^{\circ} \mathrm{C}$ and the reaction was stopped after another $5 \mathrm{~min}$ by addition of $4 \mathrm{ml}$ ice-cold phosphate-buffered saline $(0 \cdot 15 \mathrm{M}, \mathrm{pH} 7 \cdot 1)$ followed by centrifugation of the tubes. The supernatants were assayed for reduced cyt-c in an SP 1700 UV spectrophotometer (Unicam, Cambridge, England) at $550 \mathrm{~nm}$. The amount of reduced cyt-c was calculated by using an absorbance coefficient of $2.11 \times 10^{4} \mathrm{~cm}^{2} / \mathrm{mmol}^{19}$ Superoxide-dependent reduction of cyt-c is expressed as the difference in cyt-c reduction between reaction mixtures with and without SOD, as nmoles of reduced cyt-c per $10^{6}$ neutrophils.

To investigate the role of $\mathrm{PLA}_{2}$ in the pro-oxidative effects of the dihydrophenazines, 4-p-bromophenacyl bromide (BPB), an inhibitor of $\mathrm{PLA}_{2}{ }^{20}$ was added to the reaction mixture directly after SOD and ranged from $0 \cdot 25$ to $5 \cdot 0 \mu \mathrm{M}$. Following an incubation of $30 \mathrm{~min}$ at $37^{\circ} \mathrm{C}$, the test agents $(1-5 \mu \mathrm{g} / \mathrm{ml})$ and stimulants were added as previously described. 


\section{CELL VIABILITY}

Neutrophil viability was measured after a $30 \mathrm{~min}$ incubation with BPB, according to the release of lactic acid dehydrogenase $(\mathrm{LDH})$, by a standard spectrophotometric procedure. $^{21}$

\section{ARACHIDONIC ACID RELEASE BY NEUTROPHILS}

This assay was performed as previously described with some minor modifications. ${ }^{10}$ Briefly, $2 \times 10^{7} / \mathrm{ml}$ neutrophils were incubated with $5 \mu \mathrm{Ci} / \mathrm{ml}$ radiolabelled $\mathrm{AA}(5,6,8,9$, $11,12,14,15-{ }^{3} \mathrm{H}(\mathrm{N}), 100 \mathrm{Ci} / \mathrm{mmol}$, New England Nuclear Corp., Boston, Mass.) for 30 min at $37^{\circ} \mathrm{C}$, washed twice and resuspended in HBSS. After prewarming the cells for 30 min at $37^{\circ} \mathrm{C}$ the agents, administered at $10 \mu \mathrm{g} / \mathrm{ml}$ final concentration, or the corresponding solvent control were added followed by an incubation time of $10 \mathrm{~min}$ at $37^{\circ} \mathrm{C}$. The final volume in each tube was $1 \mathrm{ml}$ (HBSS). The reactions were terminated by the addition of $5 \mathrm{ml} n$-hexane/isopropanol/concentrated $\mathrm{HCl}$ (final concentration 0.1 M) 300:200:4 ( $\mathrm{vol} / \mathrm{vol} / \mathrm{vol})$, followed by vortexing. After incubation at $4^{\circ} \mathrm{C}$ overnight the tubes were again vortexed and centrifuged at $2200 \times \mathrm{g}$ for $5 \mathrm{~min}$ to separate the lipophilic and aqueous phases. The upper organic phase was collected and dried under a stream of nitrogen. The lipids were then redissolved in $100 \mu$ l of hexane/isopropanol $3: 2$ ( $\mathrm{vol} / \mathrm{vol})$. Aliquots of $10 \mu \mathrm{l}$ were spotted onto silica gel $60 \mathrm{~F} 254$ precoated thin layer chromatography (TLC) plates (Merck, Darmstadt, Federal Republic of Germany) together with $2.7 \mu \mathrm{g}$ unlabelled AA standard to facilitate visual detection. The plates were developed in chloroform/acetone $96: 4$ ( $\mathrm{vol} / \mathrm{vol}$ ) followed by exposure to iodine vapours. The AA spots were localized and the silica removed and assayed for radioactivity. The results are expressed as fmoles ${ }^{3} \mathrm{H}-\mathrm{AA} / 2 \times 10^{7}$ neutrophils.

\section{EXPRESSION AND ANALYSES OF RESULTS}

Results are expressed as mean values with standard error (SEM) for each series of experiments. Statistical analyses were performed by the Student's t-test (paired tstatistics).

\section{Results}

SUPEROXIDE PRODUCTION BY PMNL

There was no spontaneous generation of superoxide from resting cells incubated with 1 $\mu \mathrm{g} / \mathrm{ml}$ of the dihydrophenazine derivatives (results not shown). The effect of the test agents on superoxide generation of FMLP-activated neutrophils in comparison to clofazimine is shown in Figure 2. Statistically significant stimulation was found with the riminophenazines only, i.e. clofazimine, B980, B1865, B746, B718, B4021, with the exception of B670. Neither of the aposafranones, B685 and B3722, nor the imidazophenazine B621, had any effect on the amount of superoxide released by neutrophils.

The PLA $\mathrm{A}_{2}$ inhibitor BPB, inhibited the generation of superoxide from neutrophils in a dose dependent fashion (Figure 3). In assays where BPB-treated cells were stimulated with $0 \cdot 1 \mu \mathrm{M}$ FMLP, (Figure $3(\mathrm{~b})$ ) the release of superoxide was only significantly 


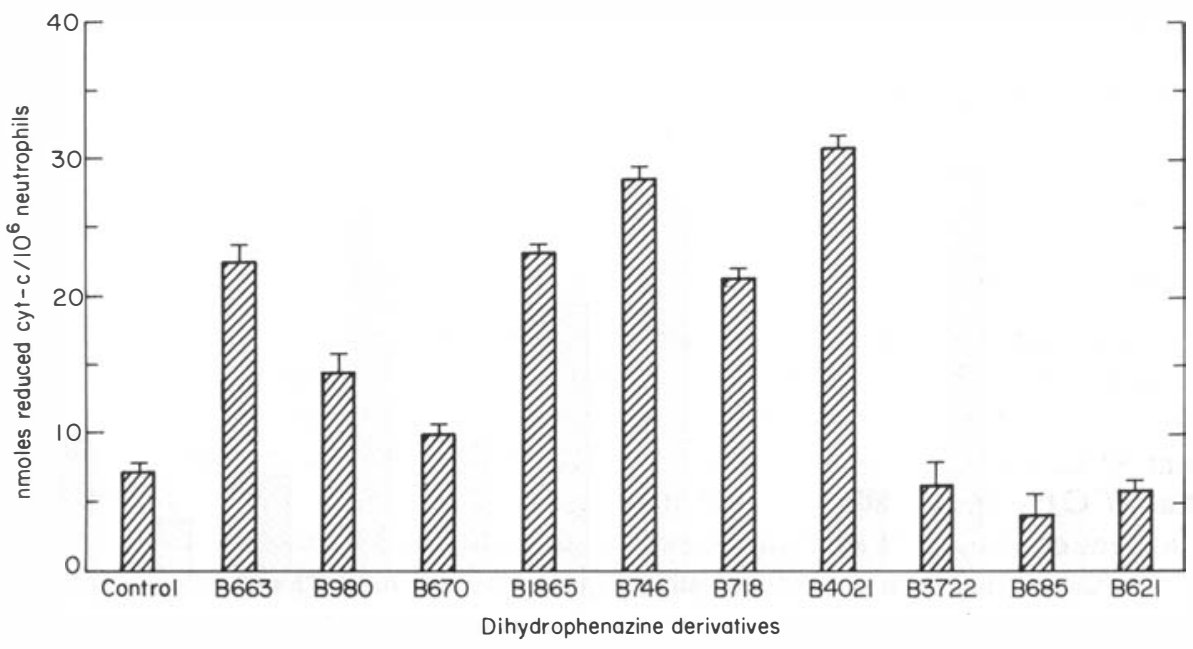

Figure 2. The effects of nine phenazine derivatives relative to clofazimine (B663) and a drug-free solvent control at a final concentration of $1 \mu \mathrm{g} / \mathrm{ml}$ on $\operatorname{FMLP}(0 \cdot 1 \mu \mathrm{M})$ activated superoxide generation by neutrophils $\left(1 \times 10^{6}\right)$ $\mathrm{ml})$. The results are expressed as nanomoles of reduced cytochrome $\mathrm{c}$ and show the mean value \pm SEM of four different experiments. Statistically significant stimulation was found with B663, B1865, B746, B718, B4021 $(p<0.005)$ and $\mathrm{B} 670(p<0 \cdot 05)$.

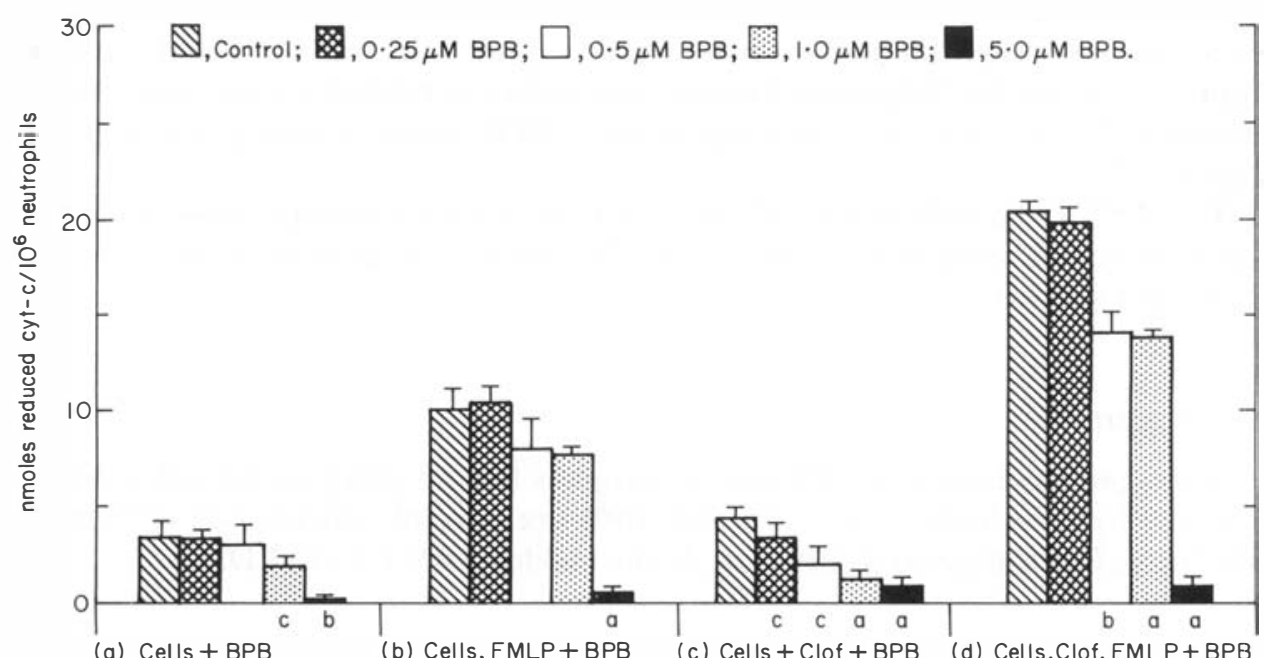

(a) Cells + BPB

(b) Cells, FMLP+BPB

(c) Cells + Clof $+B P B$

(d) Cells, Clof, FMLP+BPB

Assay systems

Figure 3. Inhibition by increasing concentrations of BPB $(0-5 \mu \mathrm{M})$ on FMLP $(0 \cdot 1 \mu \mathrm{M})$-mediated generation of superoxide from human neutrophils $\left(10^{6} / \mathrm{ml}\right)$ pre-incubated with $1 \mu \mathrm{g} / \mathrm{ml}$ clofazimine (B663). The results are expressed as nanomoles of reduced cytochrome-c and show the mean value \pm SEM for three different experiments. Inhibition of superoxide generation by BPB was significant from concentrations of BPB as low as $0.25 \mu \mathrm{M} .{ }^{\mathrm{a}} p<0.005 ;{ }^{\mathrm{b}} p<0.01 ;{ }^{\mathrm{c}} p<0.025$. 


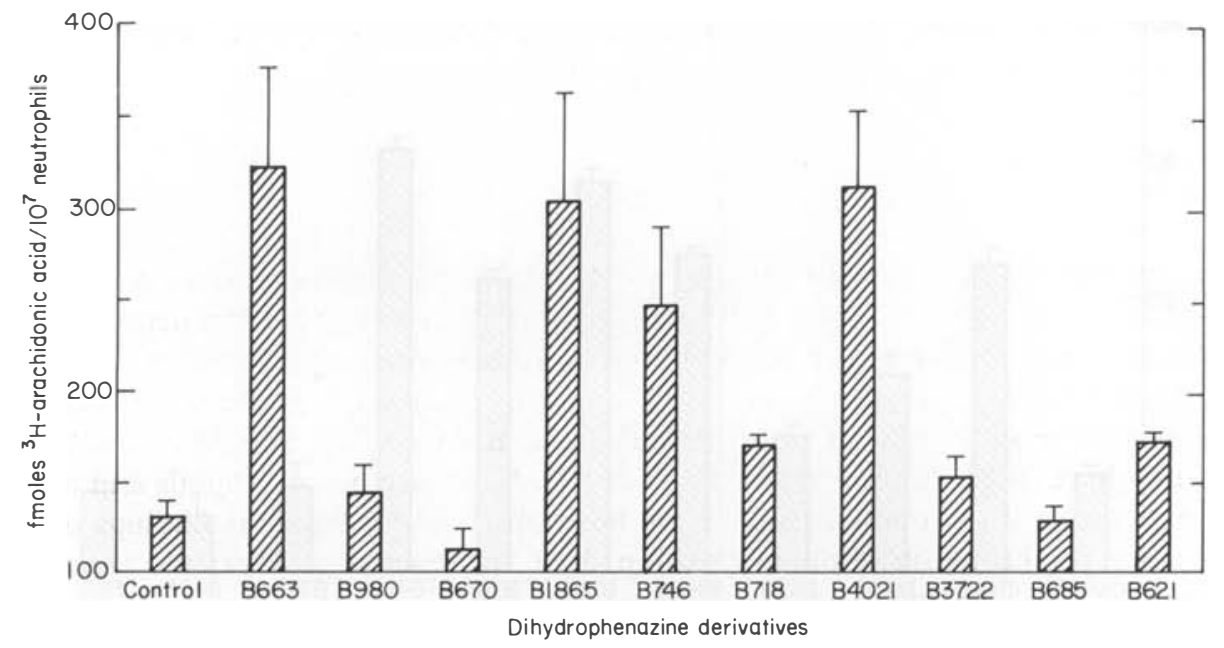

Figure 4. The effects of nine phenazine derivatives relative to clofazimine (B663) and a drug-free solvent control at a final concentration of $10 \mu \mathrm{g} / \mathrm{ml}$ on the release of arachidonic acid by neutrophils. The results are expressed as femtomoles ${ }^{3} \mathrm{H}$-arachidonic acid per $2 \times 10^{7}$ neutrophils of four different experiments. Statistically significant stimulation was found with B663, B746 $(p<0.05), \mathrm{B} 1865$ and B4021 $(p<0.025)$.

inhibited at a concentration of $5 \mu \mathrm{M}$. However, if the cells were treated with clofazimine $(1 \mu \mathrm{g} / \mathrm{ml})$ prior to stimulation, superoxide generation was inhibited by BPB concentrations greater than $0.5 \mu \mathrm{M}$, (Figure 3(d)). Furthermore, BPB only affected superoxide generation from clofazimine-free unstimulated control cells between 1 and $5 \mu \mathrm{M}$ BPB (Figure 3(a)), whilst clofazimine treated neutrophils exhibited a clear dose response inhibition of superoxide, which was significant at BPB concentrations as low as $0 \cdot 25 \mu \mathrm{M}$ (Figure 3(c)).

This BPB-mediated inhibitory effect on superoxide release by neutrophils could not be overcome by increasing the concentration of the dihydrophenazine derivatives to $5 \mu \mathrm{g} / \mathrm{ml}$ (results not shown).

\section{CELL VIABILITY}

A 30 min pre-incubation of BPB with neutrophils had no effect on the cell viability as measured by percentage release of LDH. BPB-free control cells released $4 \cdot 3 \%( \pm 0 \cdot 3)$ LDH while cells subjected to BPB for 30 min yielded $5 \cdot 0 \%( \pm 1 \cdot 0) \mathrm{LDH}$.

\section{ARACHIDONIC ACID RELEASE BY PMNL}

The effects of the nine phenazine derivatives relative to clofazimine on the release of arachidonic acid by unstimulated neutrophils are shown in Figure 4. Statistically significant stimulation was observed only with the riminophenazines clofazimine, B1865, B746 and B4021. Dose response studies of these agents over a concentration range of $0-10$ 
$\mu \mathrm{g} / \mathrm{ml}$ showed significant dose related increases of AA release at drug concentrations equal to or greater than $5 \mu \mathrm{g} / \mathrm{ml}(p<0.05-p<0.01)$.

\section{Discussion}

In the present study the effects of various dihydrophenazine derivatives on FMLPstimulated superoxide generation and spontaneous AA release of human neutrophils in comparison to clofazimine were investigated. Possible scavenging or catalytic effects of the test agents on the reduction of cyt-c were excluded using the $\mathrm{O}_{\overline{2}}$-generating xanthinexanthine oxidase system. B663 (clofazimine), B980, B670, B3722, B685 and B621 have previously been investigated for effects on superoxide release by neutrophils and results similar to those of the present study, have been observed. ${ }^{4} 16$ Previous findings on the significance of the substitution in position 2 of the phenazine molecule were also confirmed, i.e. only riminophenazines were potentially pro-oxidative while the aposafranone derivatives B3722 and B685 and the imidazophenazine B621 were inactive. ${ }^{4,16,17}$ However, this study indicated that the unchlorinated riminophenazines B670 and B718 had no effect on AA release by neutrophils compared to their chlorinated analogues B663 (clofazimine) and B746, which is also in accordance with previous findings. ${ }^{16}$ Lack of chlorination of the anilino and phenyl rings in the paraposition could however be compensated for by a chlorine substituent in position 7 of the phenazine molecule as in B1865 and B4021.

Although the specificity of BPB has been questioned, ${ }^{22}$ it is primarily a PLA $\mathrm{A}_{2}$ inhibitor and completely prevented the pro-oxidative effects of the test agents indicating the possible involvement of $\mathrm{PLA}_{2}$ in the priming mechanism. Furthermore those compounds that stimulated superoxide generation of FMLP-activated neutrophils also increased AA release from the cells, with the exception of the unchlorinated riminophenazines $\mathrm{B} 670$ and B718, which had no effect on AA mobilization. This discrepancy especially with B718 which significantly enhances superoxide generation, could be attributed to the absence and presence respectively of a stimulus (FMLP) in the AA and superoxide assays. It is probable that the riminophenazines investigated in this study mediate their pro-oxidative effects by modulation of $\mathrm{PLA}_{2}$ activity which cleaves AA from membrane phospholipids as was previously found for clofazimine. ${ }^{10}$ However alternative pro-oxidative mechanisms related to the redox properties of clofazimine and its analogues may also play a role..$^{2,23}$

Some of the agents have previously been investigated for chemotherapeutic activity in mice experimentally infected with Mycobacterium tuberculosis. ${ }^{24,25}$ The increase in median survival time of the treated mice relative to untreated controls was measured. Interestingly, the most effective agents were those which we have found to interact prooxidatively with human phagocytes. Some discrepancies are evident, e.g. clofazimine (B663) at a daily dosage of $5 \mathrm{mg} / \mathrm{kg}$ body mass increased the median survival time by 210 days, while B746 at the same dosage did soby only 45 days. ${ }^{21}$ These observations could be attributed to differences in pharmacokinetic properties.

It is concluded that only chlorinated riminophenazines are potent stimulators of spontaneous AA release from neutrophil membrane phospholipids, possibly via modulation of $\mathrm{PLA}_{2}$ activity. AA can mediate the priming effect of the agents on superoxide release from activated neutrophils. 


\section{Acknowledgment}

We wish to thank Mr R H Savage for production of the figures, and Mrs Madgwick for expert secretarial assistance.

\section{References}

1 Schulz EJ. Forty-four months' experience in the treatment of leprosy with clofazimine (Lamprene (Geigy)). Lepr Rev, 1972; 42: 178.

2 Niwa Y, Sakane T, Miyachi Y, Ozaki M. Oxygen metabolism in phagocytes of leprotic patients: Enhanced endogenous superoxide dismutase activity and hydroxyl radical generation by clofazimine. J Clin Microbiol, 1984; 20 : 837.

3 Van Rensburg CEJ, Gatner EMS, Imkamp FMJH, Anderson R. Effects of clofazimine alone or combined with dapsone on neutrophil and lymphocyte functions in normal individuals and patients with lepromatous leprosy. Antimicrob Agents Chemother, 1982; 21: 693.

4 Savage JE, O'Sullivan JF, Zeis BM, Anderson R. Investigation of the structural properties of dihydrophenazines which contribute to their pro-oxidative interactions with human phagocytes. J Antimicrob Chemother, 1989; 23: 691.

5 Anderson R. Enhancement by clofazimine and inhibition by dapsone of production of prostaglandin $\mathrm{E}_{2}$ by human polymorphonuclear leucocytes in vitro. Antimicrob Agents Chemother, 1985; 27: 257.

${ }^{6}$ Zeis BM, Anderson R. Clofazimine-mediated stimulation of prostaglandin synthesis and free radical production as novel mechanisms of drug-induced immunosuppression. Int J Immunopharmacol, 1986; 8: 731.

7 Hertz F, Cloarec A. Pharmacology of free radicals; recent views of their relation of inflammatory mechanisms. Life Sciences, 1984; 34: 713.

${ }^{8}$ Goldyne ME. Prostaglandin and the modulation of immunological responses. Int J Derm, 1977; $16: 701$.

9 Anderson R, Zeis BM, Anderson IF. Clofazimine-mediated enhancement of reactive oxidant production by human phagocytes as a possible therapeutic mechanism. Dermatologia, 1988; 176: 234.

10 Anderson R, Beyers AD, Savage JE, Nel AE. Apparent involvement of phospholipase $\mathrm{A}_{2}$ but not protein kinase $\mathrm{C}$, in the pro-oxidative interactions of clofazimine with human phagocytes. Biochem Pharmacol, 1988; 37: 4635 .

11 Clark RA, Leidal KF, Pearson DW, Nauseef WM. NADPH-oxidase of human neutrophils: subcellular localisation and characterisation of an arachidonate-activatable superoxide-generating system. $J$ Biol Chem, 1987; 262: 4065

12 Curnutte JT, Kuver R, Scott PJ. Activation of neutrophil NADPH-oxidase in a cell-free system; partial purification of components and characterisation of the activation process. J Biol Chem, 1987; 262: 5563.

13 Sakata A, Ida E, Tominaga M, Onoue K. Arachidonic acid acts as an intracellular activator of NADPHoxidase in Fc receptor-mediated superoxide generation in macrophage. J Immunol, 1987; 138: 4353.

14 Lackie JM, Lawrence AJ. Signal response transduction in rabbit neutrophil leucocytes: The effects of exogenous phospholipase A-2 suggest two pathways exist. Biochem Pharmacol, 1987; 36: 1941.

15 Bromberg Y, Pick E. Unsaturated fatty acids stimulate NADPH-dependent superoxide production by cellfree systems derived from macrophages. Cell Immunol, 1984; 88: 213.

16 Zeis BM, Anderson R, O'Sullivan JF. Prooxidative activities of ten phenazine derivatives relative to that of clofazimine. Antimicrob Agents Chemother, 1987; 31: 789.

17 Zeis BM, Anderson R, O'Sullivan JF. The effect of ten phenazine derivatives in comparison to clofazimine on the production of prostaglandin $\mathrm{E}_{2}$ by polymorphonuclear leucocytes. Lepr Rev, 1987; 58: 383.

18 Zeis BM, Anderson R, O'Sullivan JF. Inhibition of mononuclear leucocyte transformation in vitro by dihydrophenazines in comparison to clofazimine. Lepr Rev, 1988; 59: 31.

${ }_{19}$ Van Gelder BF, Slater EC. The extinction coefficient of cytochrome-c. Biochem Biophys Acta, 1962; 58: 593.

20 Roberts MF, Deens RA, Miney TC, Dennis EA. Chemical modification of the histidine residue in phospholipase $\mathrm{A}_{2}$ (Naja, Naja, Naja). J Biol Chem, 1977; 252: 2405.

${ }^{21}$ Beutler E. Red cell metabolism: A manual of biochemical methods, 3rdedn. New York: Grune \& Stratton Inc, pp. 65.

22 Chang J, Musser JH, McGregor H. Phospolipase $\mathrm{A}_{2}$ : Function and pharmacological regulation. Biochem Pharmacol, 1987; 36: 2429.

23 Barry VC, Belton JG, Conalty ML, Denneny JM, Edward DW, O’Sullivan JF, Twomey D, Winder F. A new series of phenazines (rimino-compounds) with high antituberculosis activity. Nature, 1957; 179: 1013.

${ }^{24}$ Barry VC, Conalty ML. Antituberculosis activity in the phenazine series. II. N ${ }^{3}$-substituted anilinoaposaf ranines (rimino-compounds) and some derivatives. Amer Rev Tub Pul Dis, 1958; 78: 62.

25 Barry VC, Belton JG, Conalty ML, McInerney M. Anti-tuberculosis substances XXII. Rimino-phenazines-the effects of further substitution. Proc Roy Irish Acad, 1970; 70: 179. 